\title{
Africa's Space Technology Investment and Socio-Economic Returns: The Case of Nigeria
}

\author{
Emmanuel O. Okon ${ }^{1}$ \\ ${ }^{1}$ Department of Economics, Kogi State University, Anyigba, Kogi State, Nigeria \\ Correspondence: Department of Economics, Kogi State University, Anyigba, Kogi State, Nigeria, E-mail: \\ tonydom57@yahoo.com. Tel: +2348023275716
}

Received: January 8, 2018

Accepted: January 13, 2018

Online Published: January 19, 2018

\begin{abstract}
Scientific and technological advances and innovations are fundamental to sustained economic and human development. Space exploration programs offer significant potential socio-economic benefits. Unfortunately, in Nigeria, space programme is considered to be less necessary than many other governmental initiatives, particularly in the context of sustainable development. This paper takes a look at space technology investment in Africa and application of space technology in solving socio-economic problems in the continent with a special focus on Nigeria. Also, the paper identified some challenge faced in the Nigerian space programme and made some suggestion. Nigeria must take advantage of innovations in space technology to utilize space and the by-products of space technology to make significant strides in optimizing the resources of socio-economic development and solve national problems in consonance with the global sustainable development agenda.
\end{abstract}

Keywords: Space Technology, Socio-Economic Benefits, Challenges, Nigeria, Africa.

\section{Introduction}

Science and technology are together the two major potent sources for social and economic changes in the contemporary history of mankind. Both disciplines have contributed immensely to make life comfortable for people, whether in urban or rural areas, developed or developing countries. They have helped to promote health over disease, food surplus over famine, affluence over poverty, reason over superstition, and education over ignorance (Okunola, 2001). Yet, some of the world's worst problems have either been caused or promoted by science and technology. It seems difficult to separate science from technology. However, one could see basic or pure science as a knowledge, which has been systematically assembled and put together in some sort of organized manner (Ajewole and Owolabi, 1999). On the other hand, technology is simply an applied science which falls into so many areas of engineering, business, medicine, communication, agriculture, defense, and so on. It should be noted that though, science and technology are closely related and few people rarely make a distinction between them, yet the two are not the same thing. While science is concerned with the search for knowledge and understanding about nature, technology deals with the application of the knowledge in the practical solution of problems of everyday life (Okunola, 2001).

The study, promotion and development of science and technology have come to stay in our modern world; since it has virtually permeated every aspect of human life. Its importance is buttressed by man's ability to tap materials and forces in nature in order to transform them into finished goods and services to his own advantage. Science and technology in recent times have become powerful tools for resolving societal problems worldwide. Also, one of the proper ways man searches for truth and achieves understanding of his environment and the universe at large is the science, and by extension, technology. In fact, many developed countries are lording it over the developing countries today on the basis of their exploits in the area of science and technology (Okunola, 2001).

The space sector has often been considered one of the main frontrunners of technological development, since the beginning of the space age. Benefiting from advances in related domains (e.g. material sciences), the number of 
space-related patents has almost quadrupled in fifteen years. The countries' share in space-related patents over the 2000-08 period shows the United States and Europe leading, followed by Korea and Japan OECD (2012). However, in terms of revealed technological advantage, several countries demonstrate a level of specialization in space technologies patenting, particularly the Russian Federation, France, Israel and the United States. Over the next five years, many advances are expected in the classical sphere of space applications (telecommunications and navigation applications), where satellites could contribute further to the development of commercial information systems and networks (e.g. more broadband to rural areas, high definition and 3-D television via satellite, air traffic management) OECD (2012). But in addition, several relatively new space systems could be moving from demonstrations to potentially routine systems for more countries. They include automatic identification systems (AIS) via satellite which allow countries to monitor ship traffic along their coasts, and space situational awareness, which serves to track the trajectories of operational satellites and large space debris in orbit.

Most do not associate Africa with the high-tech sphere of "space". However, Africa is none to face socio-economic challenges including desertification, water resources, locust plagues, weak educational systems, gender discrimination, planning urban development, conflict, unemployment, poverty, health, etc. Nonetheless, in recent years, many countries on the continent have woken up to the potential and usefulness of space technology (The Conversation Africa, n.d.). For instance, recognizing the significant role of space technology in the attainment of rapid sustainable socio-economic development, the Federal Government of Nigeria took a bold step by putting in place a space policy and space science and technology programme. Subsequently, in 1999, an institutional framework, the National Space Research and Development Agency (NASRDA), was established. The approval of the National Space Policy in 2001 and the implementation of the programme enunciated in it culminated in the launch of an earth observation satellite (NigeriaSat-1) in September 2003(Boroffice, 2008). By this unique achievement, Nigeria has registered not only her footprint in space but also her name as satellite data provider. This paper intends to look at space technology investment in Africa and application of space technology in solving socioeconomic problems in the continent with a special focus on Nigeria.

\section{Space Economy/Infrastructure}

Space makes the global economy what it is: universal, dynamic and productive. Remove the space dimension and the world would lose much of the growth that it has experienced in the last 50 years. Looking forward, without continuing investment in space technology and space-based services, the prospects for maintaining economic growth over the next half-century -- even the prospects of holding on to the current standard of living in the developed world -- would be bleak. In addition, and perhaps more importantly, efforts to raise the living conditions of more than half the world's population to a viable level would be severely hampered without the contribution of the space economy and the services that it makes possible (Oxford Analytica, 2008).

The global space economy is built on a space infrastructure consisting of manufacturers, service providers, and technologists in industry and government who deploy and operate launch vehicles, satellites, and space platforms such as the International Space Station. The cost of this space infrastructure is borne by commercial firms that sell satellite services; governments in many countries that use satellites to provide long-distance telephone, television, and internet to their citizens; and the national space agencies(Space foundation, n.d.).

\subsection{Demand and Supply for Space Goods and Services}

Derived demand for space activities includes the manufacture of launch vehicles and the provision of a variety of launch-related services ranging from vehicle integration (preparing the payload for launch) and spaceport activities to insurance and financing services. In addition, there are ground station equipment, software support, and satellite operations and control facilities that would not exist if there were no economic uses for space assets. At the consumer end, examples of products that are derived from the uses of space include the demand for satellite broadcasting receivers and decoders, satellite radios, and navigation (GPS) equipment. In addition to the government as a manufacturer and provider of equipment and services for its own use, there is a growing trend for the government to purchase 'off the shelf' space products ranging from transponders on telecommunications satellites to launch services and data analysis(Oxford Analytica, 2008).

The supply-side of space services is concentrated on the firms that manufacture space equipment, provide space services and operations, and market those services to end consumers. From these space specific economic activities come additions to existing product and service distribution as well as sales activities for space services. In particular, there are the wholesale and retail establishments that ship and market both consumer and capital equipment that make direct use of space information (Oxford Analytica, 2008). 
However, the benefits of space economy are delivered in several ways: directly, through the satellite construction and satellite services sectors; indirectly, through the end-use of satellite services in other businesses; and through the transfer of technology and expertise into other sectors.

American and European companies still dominate the space market, with the United States remaining the preeminent space-faring nation. But competitive pressure is increasing from emerging economies such as India and China, as well as from a revitalized Japan and a resurgent Russia. These countries are investing heavily in developing their technological base through civil and military space projects.

\section{Space Programme in Africa and Threats}

According to Adegoke (2017), the declining costs of smaller satellites along with new applications and innovations in recent years have made the implementation of space technology attainable for many African nations. In the past, the capital-intensive nature of space projects would have have been considered wasteful for developing countries. But that's always missed the point the authors say: "Assimilating space technology has the potential to accelerate the attainment of national development goals and further indicates a visionary and technology-savvy society."

Of the many vital uses of such programs, using satellites to acquire geospatial information and data is near the top of the list. Lack of data and its debilitating impact are often issues when African countries are mentioned. But owning a satellite will provide more timely and accurate information for governments to help with public health, earlywarning systems, disaster management and agribusiness decision-making rather buying data off third parties. But this is not just about the direct uses of satellites and geospatial data but also promoting a home grown culture of innovation where the country develops capabilities and gain technological learning to accelerate development. "By designating funding and resources toward a small satellite and data analysis program, a country can transfer skills and knowledge from a foreign partner to build domestic capabilities in the management and dissemination of data," write authors, Calestous Juma, Wesley L. Harris and Peter B. Waswa (Adegoke, 2017).

Several African countries now have programs in place or are starting them off for these reasons and also for security implementation. However, Ligate(2015) identified some threat associated with Africa's space programme:

Space research and exploration needs a long term vision and its will require a long period for a return. Critics easily proclaim that Africa needs to fix its basic problems of water supply, reliable electricity before embarking on grandiose and ambitious space programs.

Politicians may not view space research as a priority and popular in order to win an election. Therefore, they may not include it in their election campaign agenda. This is because poor people in Africa are more interested in getting other basic necessities solved like reliable power supply and running water. Even if a space research budget is allocated in parliament, the actual allocations for space research may decrease in favour of other priorities weakening the implementation of existing space projects.

Lack of human skills due to very few experts trained in space research disciplines and also few training institutions in the continent.

Space research and the use of its application involve a large amount of data storage, processing and transfer. Most of African countries do not have an adequate level of data protection both at the legal and regulatory levels. The lack of a robust legal and regulatory framework may be an impediment for investors in space research to invest in African countries because they are not sure that their trade secrets will be safe and whether heavy penalties will be levied to the defrauders of data.

a. African Countries with Advanced Space Programs

Here are the some top African countries that are currently running advanced space programs:

\section{South Africa}

Since 2010, South Africa has had its own space agency called the South African National Space Agency (SANSA), whose mandate is to utilize data acquired from local and international satellites to avert natural disasters like droughts and perform scientific explorations. In fact, South Africa has the largest and most active space technology on the continent(Ngugi, 2017). The program is funded by both government and private entities and uses several satellites to remotely sense potential disasters such as droughts and floods, as well as carrying out environmental studies. South Africa is the first African country to have real astronauts.

\section{Ghana}

The Ghanaian space program is the youngest in Africa, only having been established five years ago. Despite its dawdling progress, the program is a representation of the country's big ambitions. It is operated by the Ghana Space Science and Technology Center (GSSTC), whose main tasks is to coordinate research across the West African country in key areas such as satellite communications and remote sensing. Ghana plans to launch its first satellite in 2018. 


\begin{abstract}
Algeria
Established in 2002, the Algerian Space Agency (ASAL) helps the government to come up with space strategies, including the use of the country's four satellites in the facilitation of scientific research and telecommunication. The North African country hopes to use its space technology to improve its social and economic development. Recently, ASAL signed treaties with various space agencies from international partners such as France, Ukraine, Argentina, Russia, China and the United Kingdom.

\section{Egypt}

In an attempt to take its space ambitions a notch higher, Egypt recently partnered with neighboring Sudan to launch several space programs as it endeavors to build an overall African space agency. Egypt has four satellites, the first of which was launched in 1998(Ngugi, 2017). These satellites are used for ground analysis, mainly for agricultural purposes in the Nile region. They observe the country's mainland and coastal line by taking high resolution pictures of the land for environmental, scientific and security purposes.

4. Nigeria's Space Programme

Africa is realizing the benefits of space technology to socio-economic development. Several African countries now have national space programs, focused primarily on using satellite applications to address the many challenges facing these developing countries, such as managing scarce resources and providing affordable rural telecommunications. South Africa and Nigeria lead Africa in terms of their space technology capabilities (Ansdell, Delgado and Hendrickson, 2011).

Nigeria is a middle-income, mixed economy and emerging market, with expanding manufacturing, financial, service, communications, technology and entertainment sectors. It is ranked as the 21 st-largest economy in the world in terms of nominal GDP, and the 20th-largest in terms of purchasing power parity (Wikipedia, n.d.). It is the largest economy in Africa; its re-emergent manufacturing sector became the largest on the continent in 2013, and it produces a large proportion of goods and services for the West African subcontinent (Wikipedia, n.d.) (see Table 1 for a snapshot of economic indicators of Nigeria for the period 2016.
\end{abstract}

Table 1: Nigeria Economy Data

\begin{tabular}{llllll}
\hline & $\mathbf{2 0 1 2}$ & $\mathbf{2 0 1 3}$ & $\mathbf{2 0 1 4}$ & $\mathbf{2 0 1 5}$ & \multicolumn{1}{c}{$\mathbf{2 0 1 6}$} \\
\hline Population (million) & 165 & 169 & 174 & 179 & 184 \\
\hline GDP per capita (USD) & 2,708 & 2,944 & 3,182 & 2,677 & 1,976 \\
\hline GDP (USD bn) & 446 & 498 & 553 & 479 & 363 \\
\hline Economic Growth (GDP, annual variation in \%) & 4.2 & 5.5 & 6.2 & 2.8 & -1.6 \\
\hline Consumption (annual variation in \%) & 0.0 & 21.1 & 0.6 & 1.5 & - \\
\hline Investment (annual variation in \%) & 2.8 & 4.2 & 13.4 & -1.3 & - \\
\hline Industrial Production (annual variation in \%) & 1.5 & 0.0 & 5.5 & 0.3 & -5.7 \\
\hline Unemployment Rate & 7.6 & 7.1 & 4.8 & 4.3 & 5.0 \\
\hline Fiscal Balance (\% of GDP) & -1.3 & -1.4 & -0.9 & -1.6 & - \\
\hline Public Debt (\% of GDP) & 12.5 & 12.6 & 10.6 & 12.1 & 18.6 \\
\hline Money (annual variation in \%) & 16.4 & 1.3 & 20.6 & 5.9 & 16.8 \\
\hline Inflation Rate (CPI, annual variation in \%, eop) & 12.0 & 8.0 & 8.0 & 9.6 & 18.6 \\
\hline Inflation Rate (CPI, annual variation in \%) & 12.2 & 8.5 & 8.1 & 9.0 & 15.7 \\
\hline Policy Interest Rate (\%) & 12.00 & 12.00 & 13.00 & 11.00 & 14.00 \\
\hline Exchange Rate (vs USD) & 156.2 & 160.0 & 183.0 & 199.1 & 304.7 \\
\hline Exchange Rate (vs USD, aop) & 158.8 & 159.2 & 165.2 & 197.9 & 256.1 \\
\hline Current Account (\% of GDP) & 4.2 & 4.0 & 0.2 & -3.2 & 0.8 \\
\hline Current Account Balance (USD bn) & 18.9 & 20.1 & 1.3 & -15.4 & 2.7 \\
\hline Trade Balance (USD billion) & 40.9 & 43.8 & 21.0 & -6.4 & -0.5 \\
\hline Exports (USD billion) & 94.3 & 95.1 & 82.6 & 45.9 & 34.7 \\
\hline Imports (USD billion) & 53.4 & 51.4 & 61.6 & 52.3 & 35.2 \\
\hline Exports (annual variation in \%) & -2.9 & 0.8 & -13.2 & -44.4 & -24.4 \\
\hline Imports (annual variation in \%) & -14.1 & -3.8 & 19.9 & -15.0 & -32.7 \\
\hline International Reserves (USD) & 44.2 & 43.6 & 34.5 & 29.1 & 25.8 \\
\hline External Debt (\% of GDP) & 1.5 & 1.8 & 1.8 & 2.2 & 3.1 \\
\hline
\end{tabular}

Source: Focus Economy (2017) 
On top of being the largest economy in Africa, Nigeria has a highly advanced space program operated by its own space agency, the National Space Research and Development Agency (NASRDA), which was established in 2001(Ngugi, 2017). Nigeria's national space agency, the National Space Research and Development Agency (NASRDA), has the "broad objective to pursue the development and application of space science and technology for the socio-economic benefit of the nation" and the specific mission to "achieve technological competence in the manufacture and launch of satellites by the year 2025" (NASRDA, 2010). Its National Space Policy identifies space technology as "an essential tool for its socio-economic development and enhancement of the quality of life of its people" (National Space Policy, 2001), and speaks of achieving a "critical mass" of Nigerian space professionals to enable "self-reliance" in using space for national development purposes (National Space Policy, 2001). To achieve this, the policy directs government entities to pursue capacity building through international cooperation and calls for increased space-related education at all levels (Ansdell et al, 2011).

Nigeria has taken subsequent steps to fulfill its space policy. Its first satellite, NigeriaSat-1, is a remote sensing microsatellite designed to addresses national development concerns such as resource management and flood-risk mapping (Akinyede and Agbaje, 2006). NigeriaSat-1 was built under an agreement with Surrey Satellite Technology Ltd (SSTL), a British company that specializes in small satellite platforms (see Figure 1). The contract included a capacity building program to train Nigerian engineers in satellite development and operations (Boroffice, 2008).



Figure 1:NigeriaSat-1, UK-DMC-1 and BILSAT 1 flight ready. Source: Surrey (2013a)



Figure 2: NigeriaSat 2

Source: Surrey (2013b)

NigeriaSat-2 is the follow-on remote sensing mission to NigeriaSat-1, also built by SSTL and planned for launch in 2011(see Figure 2). As part of NigeriaSat-2's capacity-building program, Nigerian engineers gained hands-on experience at SSTL facilities by developing a training model, NigeriaSat-X (see Figure 3). Although not part of the original agreement, the success of NigeriaSat-X led to the decision to launch the training satellite with NigeriaSat-2. Operations will be based in Nigeria, by Nigerian operators, but with backup facilities also at SSTL (D. Wood, Interview with Danielle Wood on African Space Activities 2011). The success of NigeriaSat-X will demonstrate Nigeria's potential for independent space capabilities (Boroffice 2008).

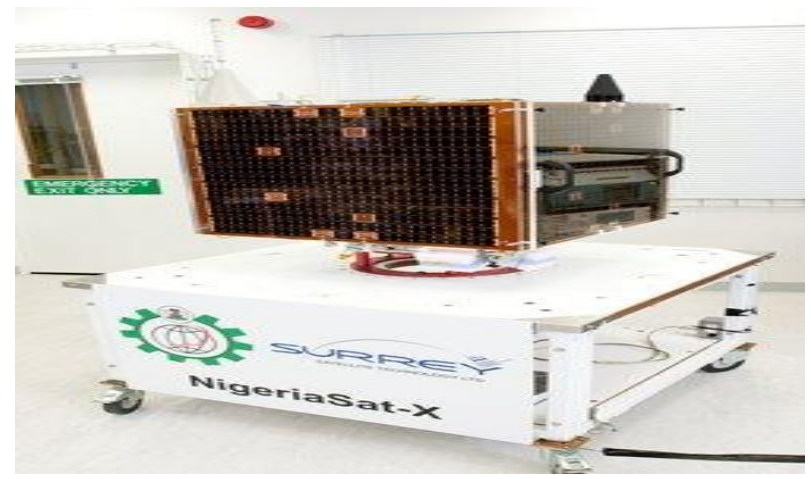

Figure 3: NigeriaSat $X$

Source: SGAC Nigeria (2012) 
NigcomSat-1 was a communications satellite built by the China Great Wall Corporation, a Chinese state-owned company. NigcomSat-1's services were to include rural mobile telephony ,tele-medicine, tele-education, and Internet - all important services for a developing country with a large population and vast geography(Ansdell et al, 2011). Unfortunately, NigcomSat-1 failed in orbit after 18months, with a replacement being built under insurance coverage for launch in 2012 (Aganaba,2010).

Despite all these, efforts toward actualizing the country's 25-year road map for space technology development have intensified with the plan to recruit possible candidates for the first Nigerian astronauts to be sent to space by the end of 2013 and the development of Assembly Integrated Testing and Design Centre (AITDC), which will enable Nigerians build satellites at home. The 25-year roadmap for space technology development approved by the Federal Executive Council (FEC) include: satellite technology development and launch (Earth observation, communication, and radar) between 2003 to 2015, launch a satellite manufactured in Nigeria by the year 2018, and launch from Nigeria launch vehicle made in Nigeria by the year 2028(Muanya, 2013).

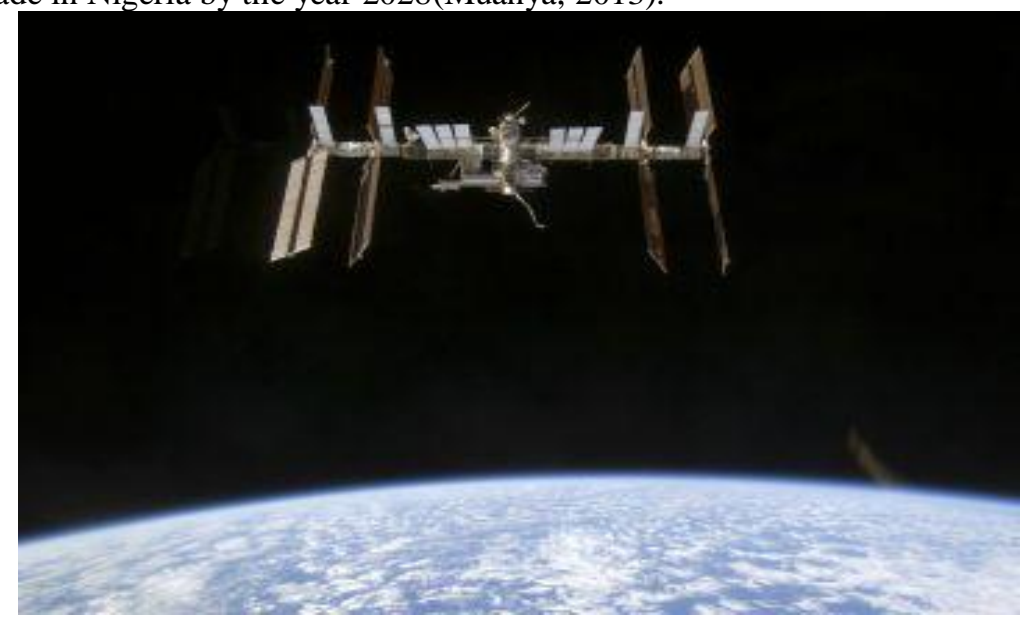

Figure 4: Nigeria has launched satellites and has plans to put an African astronaut into space. Earth is seen behind the International Space Station from Space Shuttle Discovery as the two spacecraft begin their relative separation in this photo taken Sept. 8, 2009. (NASA/Reuters)

Source: Manson (2010)

\subsection{Space Investments Returns and Nigeria's Socio-Economic Problems Solving through Space Technology}

\subsubsection{Socio-Economic Returns from Space Investment}

The investments in space programmes are often justified by the scientific, technological, industrial and security capabilities they bring (see Figure 5) (The Space Economy at a Glance 2011, n.d.). The wish to develop a specialization may allow a country to participate later on in large space programmes because of its expertise. Space investments can also provide socio-economic returns such as increased industrial activity, and bring cost efficiencies and productivity gains in other fields (e.g. weather forecasting, tele-medicine, environmental monitoring and agriculture previsions). Several space applications have reached technical maturity and have become the sources of new commercial downstream activities, sometimes far removed from the initial space research and development. For example, the growth of positioning, navigation and timing applications, which rely on satellite signals, has spurred new commercial markets (e.g. GPS chipsets in smartphones). But as Einstein wrote: "Not everything that counts, can be counted" (The Space Economy at a Glance 2011, n.d.). This is also true for the diversity of socioeconomic impacts derived from space activities. As shown in Figure 6, impacts can be categorized in different segments: new commercial products and services (including "indirect industrial effects" from space industry contracts, meaning new exports or new activities outside the space sector), productivity/efficiency gains in diverse economic sectors (e.g. fisheries, airlines), economic growth regionally and nationally, and cost avoidances (e.g. floods). 


Developing/sustaining
skilled workforce

Figure 5: Examples of motivations for developing space programmes and possible developments over time Source: Adapted from the Space Economy at a Glance 2011 (n.d.)



"Indirect industrial effects" from institutional contracts
(new exports or new activities for the space industry)

New mass market products and services using satellite capacities (e.g. satellite positioning signals in car navigation)

New products outside the space sector based on transferred technologies (e.g. medical imagery)

E.g. precision farming, fisheries, and transport

Indirect impact on the economy derived from the enduring presence of a local space industry

E.g. costs avoided and lives saved thanksto flood forecasts

Figure 6: Possible Impacts Derived from Investments in Space Programme Source: The Space Economy at a Glance 2011 (n.d.) 
A defining feature of many space-related goods and services is that their cost is tiny compared to the convenience, efficiency, information, and other benefits they yield. For example, most people would list direct-to-home television and satellite radio as space related industries, and indeed, these services provide access to television and radio to many new subscribers. Much more sweeping, however, is the use of space by broadcast and cable television. Broadcast and cable television providers rely on satellites to distribute nearly all content to cable head ends and broadcast affiliates and to transmit new feeds from location to studio.

Satellites also enable truly global internet service. Satellites are not the primary mode of Internet communications, but they extend Internet content and access in ways that current terrestrial networks simply cannot accommodate. Satellites provide intercontinental capacity to augment fiber optic cable networks that under serve certain pathways. Satellite connections have also allowed many Internet users to receive broadband service without waiting the years that it is taking in some areas to build high-speed landline connections. Long-distance telephone service via satellite was the earliest widespread space application and delivered instant telephone access among many countries. Today, many long-distance calls travel on fiber optic cables, but many nations that are not connected to cable networks due to expense or geography still depend on satellites (see Table 1 for examples of goods and services using space infrastructure).

Satellite navigation is another excellent example of the disproportionate benefits delivered by space goods and services. Global Positioning System (GPS) constellation of satellites signals allow users on land, on the sea, and in the air with inexpensive GPS devices to determine their position and, aided by computer maps (most of which were developed in part using other satellite capabilities such as remote sensing), plot a course to their destination.

Table 1: Examples of Goods and Services Using Space Infrastructure

\begin{tabular}{|c|c|}
\hline Example & Use of Space Infrastructure \\
\hline $\begin{array}{l}\text { Direct-to-home } \\
\text { television and } \\
\text { satellite radio }\end{array}$ & $\begin{array}{l}\text { Broadcast of television content directly from satellite to consumer, } \\
\text { providing access to television in rural locations and a choice of television } \\
\text { providers to many consumers. Satellite radio delivers high quality, large } \\
\text { number of channels, available anywhere radio service; } \\
\text { also, new emergency broadcast system function }\end{array}$ \\
\hline $\begin{array}{l}\text { Broadcast and } \\
\text { cable }\end{array}$ & $\begin{array}{l}\text { Content distribution to cable head ends and broadcast affiliates; } \\
\text { newsgathering; and communications infrastructure }\end{array}$ \\
\hline \multicolumn{2}{|l|}{ television } \\
\hline $\begin{array}{l}\text { Long-distance } \\
\text { telephone } \\
\text { service }\end{array}$ & \multirow[t]{2}{*}{$\begin{array}{l}\text { Communication backbone where terrestrial or undersea cables are no } \\
\text { available, typically less-developed, remote, or difficult-to-access areas, or } \\
\text { in areas where the Internet has created new traffic patterns }\end{array}$} \\
\hline $\begin{array}{l}\text { Internet } \\
\text { infrastructure }\end{array}$ & \\
\hline $\begin{array}{l}\text { Broadband } \\
\text { Internet }\end{array}$ & $\begin{array}{l}\text { Last mile connections to the Internet, mainly using very small } \\
\text { apertureterminals (VSATs). Provides quick set-up, reliable, consistent } \\
\text { capability for broadband connections to the internet used by consumers } \\
\text { and businesses of all sizes and types (purposes include credit card } \\
\text { transactions, inventory data, digital signage in stores, Internet broadband } \\
\text { connections to Internet cafes, many others) }\end{array}$ \\
\hline $\begin{array}{l}\text { Global mobile } \\
\text { telephone }\end{array}$ & $\begin{array}{l}\text { Global telephone connectivity directly to and from low Earth orbit satellite } \\
\text { systems Iridium and Globalstar }\end{array}$ \\
\hline service & \\
\hline Asset tracking & $\begin{array}{l}\text { Asset tracking using low Earth orbit satellites in combination with GPS } \\
\text { providing information on the location of, for example, fleets, RFID-tagged } \\
\text { packages, and physical inventory }\end{array}$ \\
\hline GPS & GPS satellite signal used by GPS chipset in automobiles, marine \\
\hline
\end{tabular}




\begin{tabular}{ll}
\hline $\begin{array}{l}\text { navigation, } \\
\text { positioning, } \\
\text { and } \\
\text { timing }\end{array}$ & $\begin{array}{l}\text { navigation, aviation equipment, asset tracking systems, mapping tools, and } \\
\text { cell phones }\end{array}$ \\
\hline Remote & $\begin{array}{l}\text { Remote sensing imagery (satellite images of Earth) helps monitor weather, } \\
\text { create maps, track environmental impacts such as coastline erosion and } \\
\text { pollution. Wide range of industries and applications -about one third of } \\
\text { businesses in the economy are affected by remote } \\
\text { sensing data }\end{array}$ \\
\hline
\end{tabular}

Source: Adapted from Space foundation (n.d.).

\subsubsection{Application of Space Technology in Solving Nigeria's Socio-Economic Problems}

On other continents space programmes encompass security and defence or planetary exploration, in most cases African nations - for the moment at least - are following a more practical and essential objective: communications(Quirke, 2012). Nigeria serves as a fine example. Nigeria founded its National Space Research and Development Agency (NASRDA) with the intent of developing space technology that would translate into socioeconomic benefits for its citizens. Since the launch of its first satellite in 2003, the country has come a long way in satellite technology (Baker, 2012). It has established NigComSat, an independent company which manages the commercial operations of communications satellites. The company launched NigComSat-1R in December 2011; a hybrid satellite with a 15-year lifespan that has provided improved and cost-effective wireless coverage for Nigerians (Baker, 2012). The satellite system is also a boon for national monitoring. It can map the wetlands, aid farmers in crop production, monitor desertification, find the optimum location to construct dams, assess the environmental impact of oil drilling and locate oil spills, and track border movements. To date, Nigeria has managed to sell about 1,000 of its satellite images and hopes that similar sales will cover the costs of manufacture and operation over the course of each satellite's lifetime (Manson, 2010).

Nigeria has used its satellites to monitor the oil-rich Niger Delta. Its satellites have also been used in election monitoring, providing crucial information about voters who may otherwise have been overlooked by poll workers (The Conversation Africa, n.d.). Satellites have also proved useful in the fight against extremist groups such as Boko Haram. In 2014, Nigeria used its SatX and Sat 2 to monitor the group's movements and to help find the 273 girls it had abducted (The Conversation Africa, n.d.). However, there are limits to how useful satellites can be in these situations. Finding those kidnapped proved difficult because the satellites only have a 2.5 metre resolution. This means that it cannot trace individuals' movement - it can only get maps of some locations at some particular times. Also, because satellites move from one location to another, it means that it can take up to four days for one to get into position to take a particular photograph. Nonetheless, Amnesty International has pioneered the use of satellite images for human rights research and advocacy over the past six years using imagery from GeoEye and DigitalGlobe. It has also used satellite imagery to collect information about Boko Haram's activities.

According to the Minister of Communications, Barrister Adebayo Shittu, NigComSat is one of the government agencies, with a satellite in orbit. The potentials and possibilities of this satellite are endless; from customs and excise payments, to national database creation and management, to e-passports but these services are not fully utilized (Osuagwu et al, 2017).

\section{Challenges with Space Programme in Nigeria}

Inadequate funding remains a major challenge for the implementation of space programme in Nigeria. The country is yet to develop domestic facilities and industries for indigenous satellite manufacturing and launch. Given the current status of the Nigerian space program, as well as its limited budget, it appears that Nigeria must continue its strategy of using international partnerships to fulfill its space policy, at least in the near term.

The nation's space programme is now in jeopardy, owing to power play which has consumed the Nigerian Communications Satellite Limited, NIGCOMSAT Limited, from its parent body, the National Space Research and Development Agency. The loan that was used in building the ill-fated NigComSat-1 which developed problems in the orbit is yet to be repaid with the interest pilling up even as the Chinese had replaced the object with NigGComSat III(Uja, 2012).

The poor acceptance of space technology in Nigeria has been blamed on low awareness. While the effort to boost Nigeria's space technology is laudable, many have argued that there are other aspects of the economy the 
government can channel its efforts into. Some say that Nigeria should focus on developing the satellite technology on ground first rather than make plans of going into space. Others say that going to space is going to require a huge capital investment which shouldn't be the country's priority now. Recently, the Minister of Communications in Nigeria, Barrister Adebayo Shittu, went to the Senate to demand approval to acquire two more new satellites, the argument had been if the venture will benefit Nigeria and its citizens. The situation was made worse by the minister's revelation of his intention to approach China-Exim to secure a loan of $\$ 550$ million for the purpose (Osuagwu et al, 2017). For a country undergoing recession, the National Assembly was not convinced that such a huge risk will leapfrog the country from its economic woes. On the streets, Nigerians query the benefits of the one already in orbit before making another investment in not just one, but two more. Put differently, they are asking what it will profit a nation in recession to invest in two satellites and incur a whopping $\$ 550$ million debt.

Another major challenge confronting Nigerian space programme now is the lack of Assembly Integration and Testing (AIT) centres, which is at the heart of the space programme. This centre is a spacecraft production and testing facility which will help in the indigenous realization of satellite assembly, as well as for qualification and acceptance testing from design to launch phase.

The Nigerian space program has also faced bureaucratic changes under current President Muhammadu Buhari, whose administration merged the Ministry of Science and Technology, under which the NSP was originally placed, with the Ministry of Education (Ipadeola, n.d.). Historically, major administrative mergers by the federal government of Nigeria tend to reduce efficiency rather than enhance it.

Nigeria's space ambitions are further limited by its higher education system. The country has only one university with facilities to teach and research engineering physics, a discipline crucial to space science and instrumentation. The University of Ife, now Obafemi Awolowo University, is one of the few functioning universities in Nigeria running a serious science program. The University of Nigeria is the only institution where astrophysics and astronomy are taught. But it can't afford a standard observatory. In fact, no Nigerian university or polytechnic even has a planetarium. There is clearly a great gulf to cross before Nigeria is truly space-ready (Ipadeola, n.d.).

According to Umeoguaju (n.d.), the most critical challenges facing Nigeria's Science and Technology System today are the non commercialization of successful research results, non-demand driven R\&D activities, lack of linkages between the research institutes and private sector

5.1 Way Forward

Nigeria must first and foremost convince its people that space programme is not misplaced or vainglorious project, but a genuine and worthwhile investment in its people and their future. While space programme is good for its national pride and morale, Nigerian government must be wary of sidelining its obligations to society in favor of racing to send a bigger, better satellite into orbit. As such, practical space programme adapted to the needs of the country and its budget should be pursued.

According to Agboola (2011), a lot of efforts should be geared towards capacity building in space science and technology both locally and outside the country with a view to producing highly trained scientists, engineers and technicians and transfer the knowledge gained to other sectors of the economy

There is need to setting up Assembly Integration and Testing (AIT) Centres in Nigeria. If the center is built, it will transform the research capabilities of Nigerians, Nigerian Universities and Research institutes. Also it will generate revenue locally and internationally.

There is serious need for government of Nigeria and its agencies to deepen effort toward encouraging young people in space technology. In this regard, engaging youths in space studies would reinforce their potential to use space technology for national development. In addition, the private sector should be encouraged to support Federal Government in promoting space technology in the nation given the fact that space technology is capital intensive.

The government of Nigeria must encourage the commercialization of successful research outputs are key to actualizing the country's space agenda.

6. Concluding Remarks

Nigeria sees the attainment of space capabilities as an essential tool in her socio-economic development and the enhancement of the quality of life of her people. While the sums involved can do a great deal in other aspects of government policy, the socio-economic returns from the programme can be substantial. To make Nigeria one of the top 20 economies by 2020, government should put more efforts to boost the economy through space technology. Economic growth is driven by technological innovation, and space exploration fuels this innovation. 


\section{References}

Aganaba, T. (2010). "In search of space and satellite business: Commercial spinoffs from the Nigerian space program." Space Downstream Services 2010 Conference. Tallin, Estonia.

Agboola, O. A. (2011). Space system and engineering in Africa: Nigeria as a case study. Paper Presented at the $4^{\text {th }}$ African Leadership Conference on Space Science and Technology for Sustainable Development- ALC2011. Theme: Building a shared Vision for Space in Africa. Venue: Mombasa, Kenya. Date: 26-28 September, 2011. http://www.unoosa.org/documents/pdf/psa/bsti/ALC2010/10_NIGERIA-ALC-2011ESS-V1_.pdf

Ajewole, G., and Owolabi, T. (1999).A handbook on science education for tertiary students. Lagos: Baba Olatunji Enterprises.

Akinyede, J O., and Agbaje, G. I. (2006). "Remote sensing: From pixels to processes." Proceedings from ISPRS XXXVI.Enschede, Netherlands.

Ansdell, M., Delgado, L., and Hendrickson, D. (2011). Analyzing the development pathsof emerging spacefaring nations: Opportunities or challenges for space sustainability?http://www.gwu.edu/ spi/assets/docs/Ansdell\%2520Delgado\%2520Hendrickson_Fi nal.pdf

Baker, M.( 2012). 'Africa's journey to space begins on the ground', BBC News, 10 July. http://www.bbc.co.uk.

Boroffice, R. A. (2008). "The Nigerian space programme: An update." African Skies, no. 12, 40-45. Focus Economics (2017).Nigeria Economic Outlook. https://www.focuseconomics.com/countries/nigeria.

Ipadeola, T. (n.d.).The terrestrial challenges to Nigeria's ambitious space program. http://www.slate.com/articles/technology/future_tense/2017/03/nigeria_s_ambitious_space_program_is_hel d_back_by_terrestrial_politics.html

Ligate, O. H.(2015). Space research in Africa: Challenges and opportunities. STECH,4(2), 1-17.

Manson, K. (2010). 'Coming soon: Nigerians in space?'Globalpost. http://www.globalpost.com/dispatch/nigeria/091029/nigeria-space-agency

Muanya, C. (2013).Nigeria intensifies plan to put astronauts in space by 2015. The Guardian.http://statewww.ngrguardiannews.com/index.php/science/127961-nigeria-intensifiesplan-to-put-astronauts-in-space-by-2015-

NASRDA (2010).NASRDA.2010. http://www.nasrda.gov.ng/ (accessed 2011 йил 12-January).

National Space Policy (2001). “National space policy” http://www.dawodu.com/space.pdf (accessed 2011 йил 11January).

Ngugi, F. (2017). Top 5 African countries with advanced apace programs. https://face2faceafrica.com/article/top-5african-countries-advanced-space-programs

Oxford Analytica (2008).Understanding the space economy: Competition, cooperation and commerce. A study produced for NASA.http://isulibrary.isunet.edu/opac/doc_num.php\%3Fexplnum_id\%3D290

OECD (2012). The space economy at a glance 2011.http. www.oecd.org/futures/space

Okunola, P. O. (2001). Science and technology reforms and development. The Nigeria Experience,2(4), 35-59.

Osuagwu,P., Emmanuel Elebeke, T. Y., and Nwankwo, A. (2017).Space Tech: Future of Nigeria's economy? https://www.vanguardngr.com/2017/08/space-tech-future-nigerias-economy/

Quirke, P. (2012). African space programmes: Political or scientific endeavours?http://www.consultancyafrica.com/index.php?option=com_content\&view=article\&id =1124: african-space-programmes-political-or-scientific-endeavours\&catid=57:africa-watchdiscussion-papers $\&$ Itemid $=263$

SGAC Nigeria (2012).http://spacegeneration.org/index.php/sgac-regions/africa/nigeria

Space Foundation (n.d.). America's vision: The case for space exploration, failure is not an option.http://astro.cornell.edu/ randerson/TheCaseForSpace.pdf.

Surrey (2013a).Missions.http://www.sstl.co.uk/getattachment/b5bf874e-613b-4d61-86a6-f5166418edef/N1BILSAT-UKDMC1?width $=800$

Surrey (n.d.b). NigeriaSat 2.http://space.skyrocket.de/doc_sdat/nigeriasat-2.htm.

The Conversation Africa(n.d.).Africa and space: the continent starts to look skyward. https://www.huffingtonpost.com/the-conversation-africa/africa-and-space-the-cont_b_12230148.html

The Economist (2011). 'Africa rising', 3 December. http://www.economist.com. 
The Space Economy at a Glance 2011 (n.d.).Defining socio-economic impacts from space programmes.http://dx.doi.org/10.1787/9789264111790-en

Uja,E. (2012).Nigeria's space programme in jeopardy.Vanguard.http://www.vanguardngr.com/2012/11/nigeriasspace-programme-in-jeopardy/Umeoguaju, F. (n.d.). NASRDA sees space technology as antidote to 21st century challenges.http://nigerianbioscientist.com/interact/index.php?topic=584.0;wap2

\section{Copyrights}

Copyright for this article is retained by the author(s), with first publication rights granted to the journal.

This is an open-access article distributed under the terms and conditions of the Creative Commons Attribution license (http://creativecommons.org/licenses/by/4.0/) 